\title{
Regulatory effects and molecular mechanism of Trigonostemon reidioides on lipopolysaccharide-induced inflammatory responses in RAW264.7 cells
}

\author{
JU YOUNG SHIN ${ }^{1}$, JAE-SHIN KANG ${ }^{2}$, HYE-WOO BYUN ${ }^{2}$ and EUN-KYUNG AHN ${ }^{1}$ \\ ${ }^{1}$ Bio-Center, Gyeonggi Institute of Science and Technology Promotion, Suwon, Gyeonggi 443-270; \\ ${ }^{2}$ Biological Genetic Resources Utilization Division, National Institute of Biological Resources, \\ Incheon 404-708, Republic of Korea
}

Received July 28, 2016; Accepted April 27, 2017

DOI: $10.3892 / \mathrm{mmr} .2017 .7297$

\begin{abstract}
Trigonostemon reidioides (Kurz) Craib has been traditionally used for the treatment of vomiting and asthma in Cambodia. However, the underlying molecular mechanisms of the anti-inflammatory effect of $T$. reidioides extract remains unknown. The present study investigated the anti-inflammatory activity and molecular action of an ethanol extract of $T$. reidioides (ETR) in lipopolysaccharide (LPS)-induced RAW264.7 macrophage cells. Nitric oxide assays, ELISA, reverse transcription-quantitative polymerase chain reaction and western blot analysis were used. ETR treatment inhibited the production of nitric oxide by downregulating inducible nitric oxide synthase expression, while exhibiting no significant cytotoxicity compared with macrophages treated with LPS-alone. Consequently, ETR decreased the production of certain proinflammatory cytokines, including interleukin (IL)-1 $\beta$, IL- 6 and tumor necrosis factor- $\alpha$. Additionally, ETR inhibited the activation of mitogen-activated protein kinases (MAPKs), including extracellular signal-regulated kinase, c-Jun N-terminal kinase and p38 MAPK, as well as the phosphatidylinositol 3-kinase (PI3K)/Akt signaling pathway. These effects were mediated by inhibition of the nuclear localization of nuclear factor $\kappa-\mathrm{B}(\mathrm{NF}-\kappa \mathrm{B})$. Taken together, the results of the present study demonstrate that ETR may exert an anti-inflammatory effect by inhibiting the expression of inflammatory mediators and cytokines via downregulation of the NF- $\mathrm{B}$, PI3K/Akt and the MAPK signaling pathways in LPS-stimulated macrophages. Based on these results, we hypothesize that ETR may be a potential therapeutic agent for the treatment of inflammatory disorders.
\end{abstract}

Correspondence to: Dr Eun-Kyung Ahn, Bio-Center, Gyeonggi Institute of Science and Technology Promotion, 147 Gwanggyo-ro, Suwon, Gyeonggi 443-270, Republic of Korea

E-mail: aek@gstep.re.kr

Key words: mitogen-activated protein kinases, nitric oxide, nuclear factor- $\kappa \mathrm{B}$, proinflammatory cytokines, Trigonostemon reidioides

\section{Introduction}

Trigonostemon reidioides (Kurz) Craib is a member of the Euphorbiaceae family that is native to areas in Southeast Asia, including Vietnam, Cambodia and Myanmar. The shrubs usually grow to $1.5 \mathrm{~m}$ tall and the leaves are simple and triangular. The flowers are white and sepals are obovated. The fruits are globose and $1-1.4 \mathrm{~cm}$ in diameter. The whole herbs have been traditionally used for vomiting diseases and asthma in Cambodia (1). Soonthornchareonnon et al (2) reported that an extract and rediocides isolated from $T$. reidioides roots exhibited acaricidal activity on Dermatophagoides pteronyssinus, the Thai common house dust mite. However, the underlying molecular mechanisms of the anti-inflammatory effect of T. reidioides extract or its components remain unknown.

Inflammation is a general defense response against a variety of stimulators. When inflammation occurs, several inflammatory mediators are produced, resulting in symptoms that include pain, fever, erythema and edema (3). One of the most potent stimuli for macrophages is the bacterial endotoxin lipopolysaccharide (LPS), which activates cells by causing the secretion of various proinflammatory mediators, including tumor necrosis factor $\alpha$ (TNF- $\alpha$ ), interleukin-6 (IL-6), cyclooxygenase-2 (COX-2), and inducible nitric oxide synthase (iNOS) $(4,5)$. The expression of proinflammatory cytokines, including TNF- $\alpha$ and IL-6, is controlled by mitogen-activated protein kinases (MAPKs). MAPKs include extracellular signal-regulated kinase (ERK), p38 kinase (p38) and c-Jun N-terminal kinase (JNK) (6). Nuclear factor- $\kappa \mathrm{B}(\mathrm{NF}-\kappa \mathrm{B})$ is involved in the expression of genes associated with immunity and inflammation, and it is also associated with the activation of MAPKs and the phosphatidylinositol 3-kinase (PI3K)/Akt signaling pathway $(3,7,8)$.

The present study investigated the anti-inflammatory effect and associated molecular mechanisms of an ethanol extract of $T$. reidioides (ETR) on LPS-stimulated inflammatory responses in RAW264.7 cells.

\section{Materials and methods}

Reagents. Dulbecco's modified Eagle's medium (DMEM) and fetal bovine serum (FBS) were purchased from Gibco 
(Thermo Fisher Scientific, Inc., Waltham, MA, USA). Dimethyl sulfoxide (DMSO) and MTT were purchased from Duchefa Biochemie B.V (Haarlem, The Netherlands). $N$-(1-naphthyl) ethylenediamine dihydrochloride (Griess reagent) and sulfanilamide were purchased from Merck KGaA (Darmstadt, Germany). LPS from Escherichia coli serotype 0111:B4, bovine serum albumin, radioimmunoprecipitation assay (RIPA) buffer, protease inhibitor, phosphatase inhibitor and NG-methyl-L-arginine acetate salt (L-NMMA) were purchased from Sigma-Aldrich (Merck KGaA). LY294002, SP600125, rabbit monoclonal anti- $\beta$-actin (cat. no. 5125), anti-phospho-Akt (cat. no. 4060), anti-Akt (cat. no. 9272), anti-phospho-JNK (T183/Y185; cat. no. 4668), anti-JNK (cat. no. 9252), anti-phospho-ERK (T202/Y204; cat. no. 9101), anti-ERK (cat. no. 9102), anti-phospho-p38 (T180/Y182; cat. no. 9211), anti-p38 (cat. no. 9212), anti-NF-kB p65 (cat. no. 8242) and anti-NF-кB p50 (cat. no. 12540) primary antibodies (dilution, 1:1,000) and anti-rabbit horseradish peroxidase-conjugated immunoglobulin (Ig) G (cat. no. 7074; dilution, 1:2,000) were purchased from Cell Signaling Technology, Inc. (Danvers, MA, USA). Rabbit polyclonal anti-iNOS antibody (ab3523; dilution, 1:500) was purchased from Abcam (Cambridge, UK). Goat polyclonal anti-Lamin B (cat. no. sc-6216; dilution, 1:1,000) and mouse anti-goat horseradish peroxidase conjugated $\operatorname{IgG}$ (cat. no. sc-2354; dilution, 1:5,000) were purchased from Santa Cruz Biotechnology, Inc. (Dallas, TX, USA).

Plant material. The dried stems of T. reidioides were obtained from Siem Pang in north-east Cambodia in May 2015 and were identified by Dr Jae-Shin Kang (Biological Genetic Resources Utilization Division, National Institute of Biological Resources, Incheon, Korea). A voucher specimen (NIBRVP0000530014) was deposited at the National Institute of Biological Resources (Incheon, Korea).

Preparation of extract. Stems of T. reidioides (175 g) were pulverized and the dry material was extracted with $70 \%$ ethanol for $24 \mathrm{~h}$ at room temperature. The extract was filtered and concentrated in a vacuum under reduced pressure (temperature, $40^{\circ} \mathrm{C}$; pressure, $10 \mathrm{hPa}$ ) using a rotary flash evaporator (Büchi Labortechnik AG, Flawil, Switzerland), allowing for complete evaporation of the ethanol. The remaining aqueous solution was concentrated under vacuum (temperature, $-85^{\circ} \mathrm{C}$; pressure, $5 \mathrm{mTorr}$ ) and freeze-dried. The yield of the crude ETR extract was $4 \%(w / w)$.

Cell culture. Murine macrophage RAW264.7 cells were obtained from American Type Culture Collection (Manassas, VA, USA). Cells were cultured at $37^{\circ} \mathrm{C}$ with $5 \% \mathrm{CO}_{2}$ in DMEM supplemented with $10 \%$ FBS and $1 \%$ penicillin $(100 \mathrm{U} / \mathrm{ml})$-streptomycin $(100 \mu \mathrm{g} / \mathrm{ml})$ (Invitrogen; Thermo Fisher Scientific, Inc.).

Cell viability. RAW264.7 cells were plated at a density of $5 \times 10^{4}$ cells/well in 96-well plates and treated with ETR $(25-100 \mu \mathrm{g} / \mathrm{ml})$ and L-NMMA $(100 \mu \mathrm{M})$ for $1 \mathrm{~h}$ prior to LPS $(1 \mu \mathrm{g} / \mathrm{ml})$ stimulation for $24 \mathrm{~h}$. Following culture for $24 \mathrm{~h}$, $100 \mu 1$ MTT solution $(5 \mathrm{mg} / \mathrm{ml}$ in PBS, $\mathrm{pH}$ 7.4) was added to each well. After $2 \mathrm{~h}$ of incubation at $37^{\circ} \mathrm{C}$ with $5 \% \mathrm{CO}_{2}$, the supernatant was removed and formazan crystals formed by viable cells were dissolved in DMSO. The absorbance of each well was measured at a wavelength of $540 \mathrm{~nm}$ using a SpectraMax 190PC microplate reader (Molecular Devices, LLC, Sunnyvale, CA, USA). Data are presented as the mean \pm standard deviation of three replicates.

Nitric oxide (NO) production assay. RAW264.7 cells were plated at a density of $5 \times 10^{4}$ cells/well in 96-well plates and treated with ETR $(25-100 \mu \mathrm{g} / \mathrm{ml})$ and L-NMMA $(100 \mu \mathrm{M})$ for $1 \mathrm{~h}$ prior to LPS $(1 \mu \mathrm{g} / \mathrm{ml})$ stimulation for $24 \mathrm{~h}$. Equal volumes of cultured medium and Griess reagent were mixed and incubated at room temperature for $10 \mathrm{~min}$. Absorbance was subsequently measured at $540 \mathrm{~nm}$, using a SpectraMax 190PC microplate reader.

Enzyme-linked immunosorbent assay (ELISA). RAW264.7 cells were plated at a density of $1 \times 10^{6}$ cells/well in 6-well plates and treated with ETR $(25-100 \mu \mathrm{g} / \mathrm{ml})$ for $1 \mathrm{~h}$ prior to LPS $(1 \mu \mathrm{g} / \mathrm{ml})$ stimulation for $24 \mathrm{~h}$. Levels of the proinflammatory cytokines IL-1 $\beta$ (cat. no. BMS6002), TNF- $\alpha$ (cat. no. BMS607-3) and IL-6 (cat. no. BMS603-2) were measured in cell culture supernatants using ELISA kits (Invitrogen; Thermo Fisher Scientific, Inc.), according to the manufacturer's protocol.

Reverse transcription polymerase chain reaction (RT-PCR). RAW264.7 cells were plated at a density of $1 \times 10^{6}$ cells/well in 6-well plates and treated with ETR $(25-100 \mu \mathrm{g} / \mathrm{ml})$ for $1 \mathrm{~h}$ prior to LPS $(1 \mu \mathrm{g} / \mathrm{ml})$ stimulation for $24 \mathrm{~h}$. Total RNA was prepared from cells using TRIzol reagent (Invitrogen; Thermo Fisher Scientific, Inc.) and $1 \mu \mathrm{g}$ RNA was used as a template for each RT-PCR reaction. RT-PCR was performed using the SuperScript ${ }^{\circledR}$ III First-Strand Synthesis System (Thermo Fisher Scientific, Inc.) and Taq DNA polymerase (Invitrogen; Thermo Fisher Scientific, Inc.). The following conditions were used for each PCR reaction: $95^{\circ} \mathrm{C}$ for $5 \mathrm{~min}$ (1 cycle); $95^{\circ} \mathrm{C}$ for $30 \mathrm{sec}, 55^{\circ} \mathrm{C}$ for $40 \mathrm{sec}$ and $72^{\circ} \mathrm{C}$ for $1 \mathrm{~min}$ (30 cycles); and a final extension phase at $72^{\circ} \mathrm{C}$ for $10 \mathrm{~min}$. The following primers (Bioneer Corporation, Daejeon, Korea) were used for PCR amplification: IL-1 $\beta, 5^{\prime}$-CTTTGA AGAAGAGCCCATCC-3' (sense) and 5'-TTTGTCGTTGCT TGGTTCTC-3' (antisense); IL-6, 5'-CACTTCACA AGT CGGAGGCTT-3' (sense) and 5'-GCAAGTGCATCATCG TTGTTC-3' (antisense); TNF- $\alpha, 5^{\prime}$-CTGAGACAATGAACG CTACA-3' (sense) and 5'-TTCTTCCACATCTATGCCAC-3' (antisense); iNOS, 5'-GAGTTCGAGACTTCTGTGA-3' (sense) and 5'-GGCGATCTGGTAGTAGTG-3' (antisense); and GAPDH, 5'-CAGGTACCAGGAGAGTG-3' (sense) and 5'-GTAGACTCCACGACATCTC-3' (antisense). Bands of interest were visualized using a ChemiDoc XRS system and Quantity One software version 4.6.3 (Bio-Rad Laboratories, Inc., Hercules, CA, USA).

Preparation of nuclear extract. Following treatment as indicated, cells were washed two times with PBS prior to trypsinization and centrifugation at $90 \mathrm{xg}$ and $4^{\circ} \mathrm{C}$ for $5 \mathrm{~min}$. Cells were resuspended in PBS, centrifuged at $20,000 \mathrm{x} \mathrm{g}$ at $4^{\circ} \mathrm{C}$ for $5 \mathrm{~min}$ and resuspended in $200 \mu \mathrm{l}$ buffer $(10 \mathrm{mM}$ HEPES at pH 7.9; $10 \mathrm{mM} \mathrm{KCl;} 1 \mathrm{mM}$ DTT; 0.5 mM PMSF; and $0.1 \mathrm{mM}$ 
EDTA). After incubation on ice for $10 \mathrm{~min}$, cells were lysed by the addition of $12.5 \mu 110 \% \mathrm{NP}-40$. Cells were then centrifuged at 20,000 $\mathrm{xg}$ for $2 \mathrm{~min}$ at $4^{\circ} \mathrm{C}$, and the supernatants were collected as a cytosolic extract. Pellets were resuspended in $50 \mu$ l extraction buffer (20 mM HEPES at pH 7.9; $0.4 \mathrm{M} \mathrm{NaCl}$; 1 mM DTT; 1 mM PMSF; 1 mM EDTA; and 1\% NP-40) and incubated on ice for $10 \mathrm{~min}$. The nuclear extract was collected by centrifugation at $15,000 \mathrm{xg}$ for $15 \mathrm{~min}$ at $4^{\circ} \mathrm{C}$.

Western blot analysis. RAW264.7 cells were plated at a density of $1 \times 10^{6}$ cells/well in 6-well plates and treated with ETR $(25-100 \mu \mathrm{g} / \mathrm{ml}), \operatorname{SP} 600125(25 \mu \mathrm{M})$ or LY294002 $(25 \mu \mathrm{M})$ for $1 \mathrm{~h}$ prior to LPS $(1 \mu \mathrm{g} / \mathrm{ml})$ stimulation for different lengths of time, as indicated in the figure legends. Cells were washed twice with PBS and lysed with RIPA buffer containing protease inhibitors and phosphatase inhibitor. Cell lysates were centrifuged at $13,000 \mathrm{x}$ g for $10 \mathrm{~min}$ at $4^{\circ} \mathrm{C}$, and the supernatants were subjected to western blot analysis as described previously $(9,10)$. All western blots are representative of at least three independent experiments.

Statistical analysis. The statistical significance of the differences between groups was assessed using a Student's t-test for pair-wise comparisons or a one-way analysis of variance followed by a post hoc Dunnett's test for multiple comparisons. Statistical analysis was performed using Microsoft Excel software version 2007 (Microsoft Corporation, Redmond, WA, USA). Data are expressed as the mean \pm standard deviation of at least three independent experiments. $\mathrm{P}<0.05$ was considered to indicate a statistically significant difference.

\section{Results}

Effect of ETR on cell viability and NO production in LPS-stimulated RAW264.7 cells. To investigate the effect of ETR treatment on LPS-induced inflammatory responses, the present study first evaluated cell viability following treatment with ETR, using the MTT assay. As demonstrated in Fig. 1A, ETR at concentrations up to $100 \mu \mathrm{g} / \mathrm{ml}$ did not cause significant cytotoxicity in LPS-induced RAW264.7 cells, compared with cells treated with LPS alone. Subsequently, the effect of ETR treatment on NO production in response to LPS stimulation was investigated. It is established that NO functions as a proinflammatory mediator in the pathogenesis of inflammation (11). In the present study, ETR treatment significantly inhibited LPS-induced NO production in a dose-dependent manner, with a half maximal inhibitory concentration $\left(\mathrm{IC}_{50}\right)$ of $38.58 \mu \mathrm{g} / \mathrm{ml}$. Treatment with $100 \mu \mathrm{g} / \mathrm{ml}$ ETR resulted in an effect similar to that of treatment with $100 \mu \mathrm{M}$ L-NMMA, which is an inhibitor of NOS (Fig. 1B). Therefore, these results demonstrated that ETR may exhibit an anti-inflammatory effect via suppression of NO production without cytotoxicity in LPS-stimulated macrophages.

Effect of ETR on expression of iNOS and proinflammatory cytokines in LPS-stimulated RAW264.7 cells. The effect of ETR on LPS-induced iNOS expression was investigated by RT-PCR and western blotting. iNOS has an important role in inflammation-induced NO production, and mediates immune system regulation and inflammatory reactions (12).
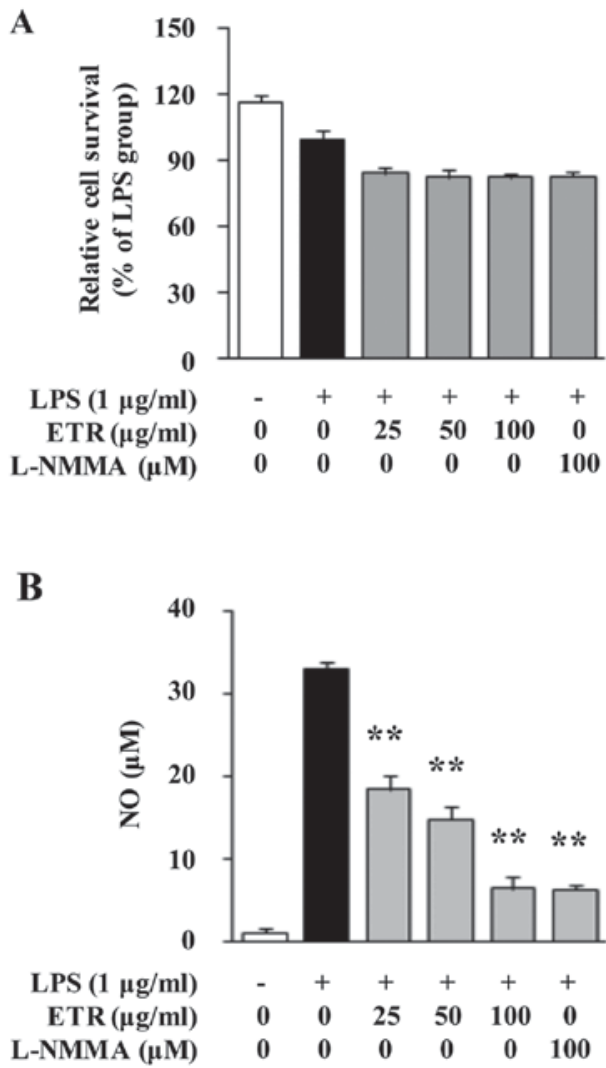

Figure 1. Effect of ETR on cytotoxicity and NO production in LPS-stimulated RAW264.7 cells. (A) Cytotoxicity of ETR was determined by MTT assay. (B) $\mathrm{NO}$ production was determined by measuring the concentrations of $\mathrm{NO}_{2}$ and $\mathrm{NO}_{3}{ }^{-}$in cell culture supernatants. L-NMMA $(100 \mu \mathrm{M})$ was used as a positive control. Data are presented as the mean \pm standard deviation of three independent replicates. ${ }^{* *} \mathrm{P}<0.01$ vs. LPS-treated cells. ETR, ethanol extract of Trigonostemon reidioides (Kurz) Craib; NO, nitric oxide; LPS, lipopolysaccharide; L-NMMA, NG-methyl-L-arginine acetate salt.

As demonstrated in Fig. 2A, ETR treatment at concentrations of 50 and $100 \mu \mathrm{g} / \mathrm{ml}$ inhibited LPS-induced iNOS expression in a dose-dependent manner at the mRNA and protein levels in RAW264.7 cells. These results indicated that ETR may suppress the LPS-induced NO production by downregulating iNOS expression in RAW264.7 cells.

Proinflammatory cytokines, including TNF- $\alpha$, IL-1 $\beta$ and IL-6, are released from macrophages upon stimulation with LPS or other inflammatory stimuli $(13,14)$. To evaluate whether the reduction in NO affects the inflammatory response, the expression of these proinflammatory cytokines were examined by RT-PCR and ELISA. As presented in Fig. 2B, ETR treatment inhibited the expression of TNF- $\alpha$, IL-1 $\beta$ and IL-6 in a dose-dependent manner at the mRNA level. In addition, protein levels of IL-1 $\beta$ and IL- 6 as determined by ELISA were significantly reduced by ETR treatment compared with LPS-treated cells; ETR treatment at $100 \mu \mathrm{g} / \mathrm{ml}$ inhibited IL-1 $\beta$ and IL- 6 production by 85.47 and $96.24 \%$, respectively (Fig. 2C). These results indicated that ETR may regulate the transcription and protein secretion of proinflammatory cytokines in LPS-activated macrophages.

Effect of ETR on NF- $\kappa B$ nuclear translocation in $L P S$-stimulated RAW264.7 cells. NF- $\kappa \mathrm{B}$ activation leads to the production and release of pro-inflammatory proteins (15-17). 

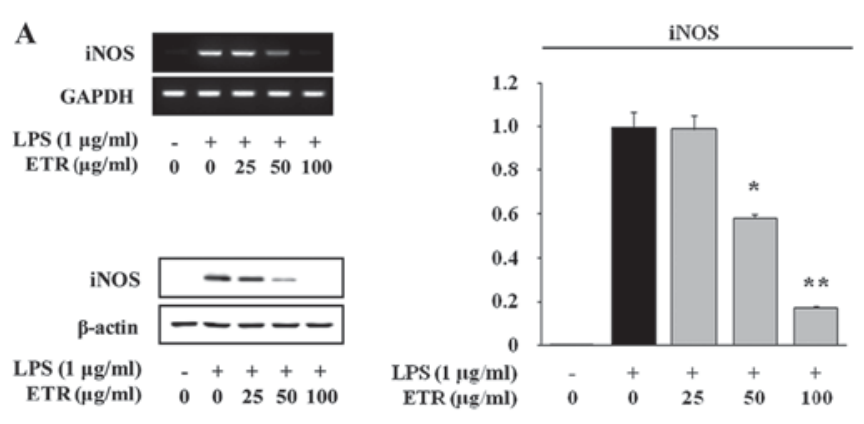

B

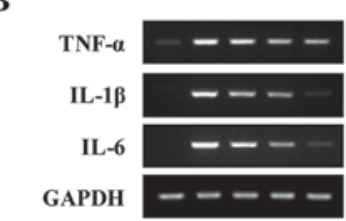

$\operatorname{LPS}(1 \mu \mathrm{g} / \mathrm{ml}) \quad-++++$ $\operatorname{ETR}(\mu \mathrm{g} / \mathrm{ml}) \quad 0 \quad 0 \quad 25 \quad 50100$
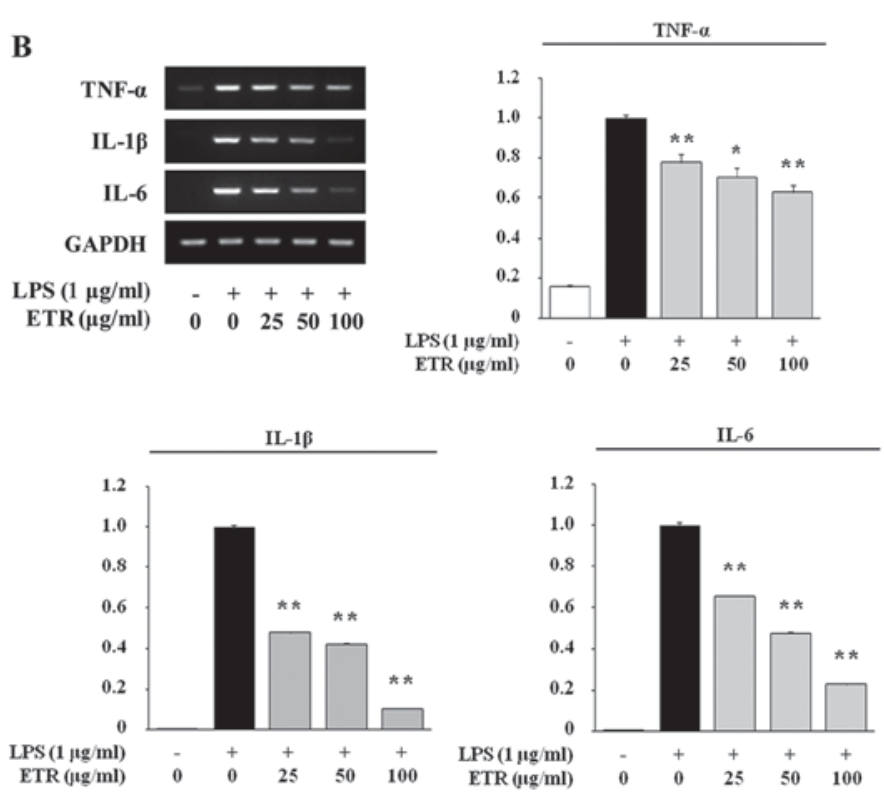
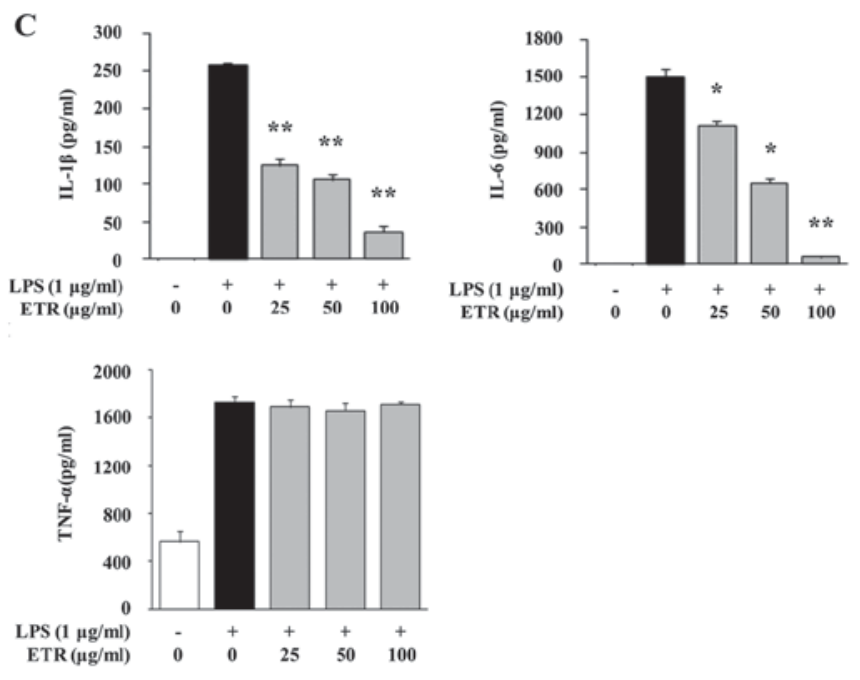

Figure 2. Effect of ETR on the expression of iNOS and proinflammatory cytokines in LPS-stimulated RAW264.7 cells. (A) Expression levels of iNOS mRNA (top) and protein (bottom) were determined by RT-PCR and western blotting. GAPDH and $\beta$-actin served as internal controls for RT-PCR and western blotting, respectively. (B) Expression levels of TNF- $\alpha$, IL-1 $\beta$ and IL-6 mRNA were determined by RT-PCR. (C) Concentrations of IL-1 $\beta$, TNF- $\alpha$ and IL-6 cytokines in cell culture supernatants were determined by ELISA. Data are presented as the mean \pm standard deviation of three independent replicates. ${ }^{*}<0.05$ and ${ }^{* *} \mathrm{P}<0.01$ vs. LPS-treated cells. ETR, ethanol extract of Trigonostemon reidioides (Kurz) Craib; iNOS, inducible nitric oxide synthase; LPS, lipopolysaccharide; RT-PCR, reverse transcription-polymerase chain reaction; TNF, tumor necrosis factor; IL, interleukin.

$\mathrm{NF}-\kappa \mathrm{B}$ is normally present in the cytoplasm of non-stimulated cells, and nuclear translocation of $\mathrm{NF}-\kappa \mathrm{B}$ is required for it to initiate transcription of inflammation-associated target genes (18). The present study investigated whether ETR inhibits the translocation of $\mathrm{NF}-\kappa \mathrm{B}$ (p65 and p50 subunits) into the nucleus. As demonstrated in Fig. 3, ETR treatment $(100 \mu \mathrm{g} / \mathrm{ml})$ markedly suppressed the nuclear translocation of p65 and p50 subunits in LPS-stimulated RAW264.7 cells. This result indicated that ETR may regulate LPS-induced inflammatory mediators and the expression of proinflammatory cytokines by inhibition of the NF- $\mathrm{NB}$ signaling pathway.

Effect of ETR on the phosphorylation of MAPKs and Akt in LPS-stimulated RAW264.7 cells. MAPKs and Akt are involved in signaling pathways that contribute to the regulation of macrophage inflammatory mediators via activation of transcription factors, particularly $\mathrm{NF}-\kappa \mathrm{B}(13,19,20)$. To determine the underlying molecular mechanism by which ETR acts on the LPS-induced inflammatory response, the present study investigated the phosphorylation of Akt, ERK, JNK and p38 MAPK by western blot analysis. As presented in Fig. 4A, ETR treatment reduced the phosphorylation of

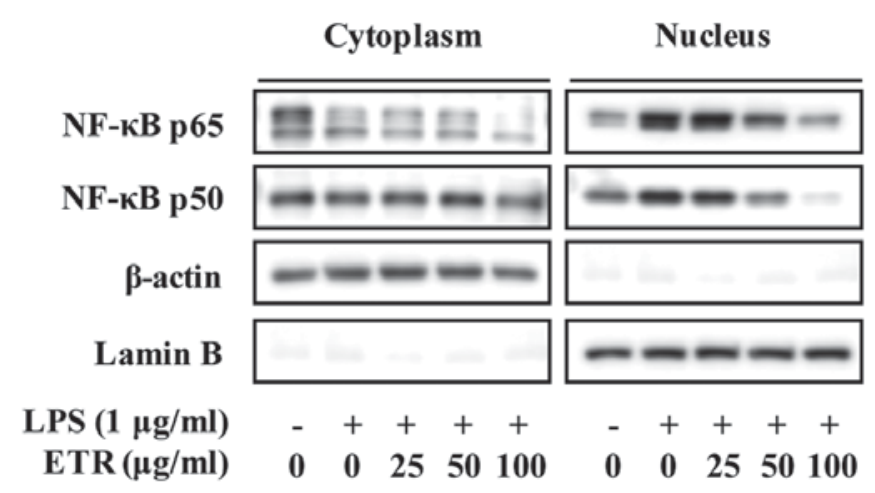

Figure 3. Effect of ETR on the nuclear translocation of NF- $\mathrm{KB}$ in LPS-stimulated RAW264.7 cells. Cells were pretreated with ETR $(25-100 \mu \mathrm{g} / \mathrm{ml})$ for $1 \mathrm{~h}$, followed by LPS $(1 \mu \mathrm{g} / \mathrm{ml})$ stimulation for $30 \mathrm{~min}$. Cytosolic and nuclear extracts were analyzed via western blotting with

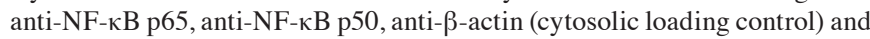
anti-Lamin B (nuclear loading control) antibodies. Images are representative of three independent replicates. ETR, ethanol extract of Trigonostemon reidi-

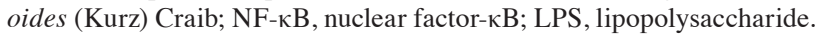

Akt, JNK and p38 MAPK in LPS-stimulated RAW264.7 cells, however, no effect on the phosphorylation of ERK was 
A

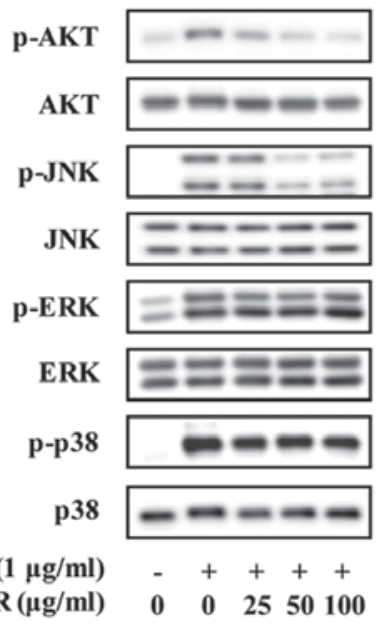

B

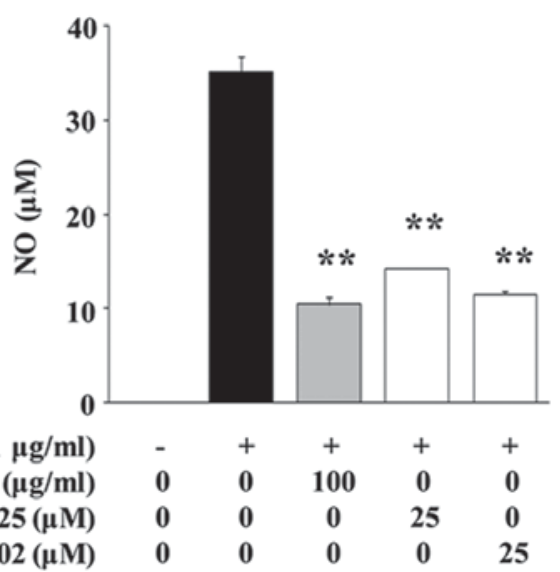

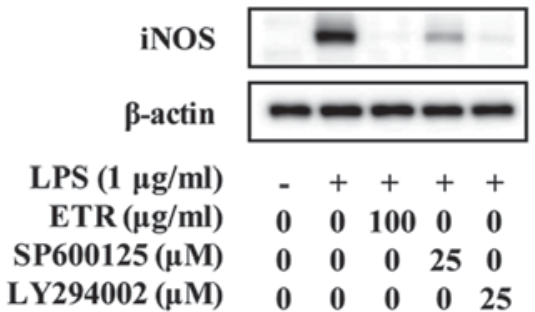

Figure 4. Effect of ETR on the phosphorylation of Akt and mitogen-activated protein kinases in LPS-stimulated RAW264.7 cells. Cells were pretreated with ETR $(25-100 \mu \mathrm{g} / \mathrm{ml})$ for $1 \mathrm{~h}$, followed by LPS $(1 \mu \mathrm{g} / \mathrm{ml})$ stimulation for $30 \mathrm{~min}$. (A) Cell lysates were subjected to western blot analysis with anti-p-Akt, anti-Akt, anti-p-ERK, anti-ERK, anti-p-JNK, anti-JNK, anti-p-p38 and anti-p38 antibodies. (B) Cells were pretreated with ETR (100 $\mu$ g/ml), LY294002 $(25 \mu \mathrm{M})$ or SP600125 $(25 \mu \mathrm{M})$ for $1 \mathrm{~h}$, followed by LPS $(1 \mu \mathrm{g} / \mathrm{ml})$ stimulation for $24 \mathrm{~h}$. NO production was determined by NO assay using Griess reagent, and iNOS expression was analyzed by western blot analysis. Data are presented as the mean \pm standard deviation of three independent replicates. ${ }^{* *} \mathrm{P}<0.01$ vs. LPS-treated cells. ETR, ethanol extract of Trigonostemon reidioides (Kurz) Craib; LPS, lipopolysaccharide; p-, phosphorylated-; ERK, extracellular signal-regulated kinase; JNK, c-Jun N-terminal kinase; NO, nitric oxide; iNOS, inducible nitric oxide synthase.

observed. Notably, the phosphorylation of Akt and JNK was almost completely inhibited by ETR treatment at 50 and $100 \mu \mathrm{g} / \mathrm{ml}$. Kyriakis and Avruch (21) and Jung et al (22) have reported that iNOS expression was promoted by the PI3K/Akt and MAPK signal transduction pathways in LPS-stimulated macrophages. To confirm that the MAPKs and the PI3K/Akt pathway are involved in the anti-inflammatory effect of ETR on LPS-activated macrophages, the inhibitory effect of ETR on NO production and iNOS expression was investigated in the presence of SP600125, a JNK-specific inhibitor, and LY294002, an Akt-specific inhibitor. NO production and iNOS expression in the LPS-activated macrophages were significantly suppressed by treatment with either ETR, SP600125 or LY294002 compared with macrophages treated with LPS alone (Fig. 4B). These data indicated that the inhibitory effect of ETR on LPS-induced inflammation may involve the PI3K/Akt and MAPK signaling pathways.

\section{Discussion}

Inflammation is a physiological response that is mediated by activating various immune cells, including macrophages and monocytes. Inflammation serves a key role in the host defense system. Excessive inflammation causes a variety of diseases, including arthritis, inflammatory bowel disease, neurodegenerative disorders and septic shock syndrome $(23,24)$. Inflammatory responses are regulated by NO, which is synthesized by NOS. In particular, iNOS is regarded as the primary regulator of $\mathrm{NO}$ production in macrophages $(25,26)$.

T. reidioedes has been described as exhibiting potential anticancer activity by inducing cytotoxicity in several cancer cell lines, including liver, cervical, oral, colon, lung and gastric cancers (1). Recently, several studies have reported that natural products such as $T$. reidioedes may be effective in the treatment and prevention of inflammatory diseases $(27,28)$. However, there have been few reports investigating the molecular mechanisms of the inflammatory effect of T. reidioedes. In the present study, to determine these underlying mechanisms, the anti-inflammatory activity of ETR was investigated. The results demonstrated that ETR treatment reduced NO production and the expression of various proinflammatory mediators, including iNOS, IL- $1 \beta$, IL- 6 and TNF- $\alpha$ in LPS-induced RAW264.7 cells.

The transcription factor NF- $\kappa \mathrm{B}$ has a critical role in the regulation of inflammatory gene expression (27). It has been previously established that NF- $\mathrm{KB}$ activation is related to the MAPK and the PI3K/Akt signaling pathway, through LPS stimulation (28-30). In the present study, ETR treatment inhibited NF- $\kappa B$ activation and the phosphorylation of JNK and Akt. Of note, treatment with SP600125 and LY294002, inhibitors of JNK and Akt phosphorylation respectively, significantly inhibited the expression of NO and iNOS in the LPS-activated macrophages, an effect that was similar to the ETR treatment. These data suggested that the ETR anti-inflammatory effect may involve the PI3K/Akt and MAPK signaling pathways.

In conclusion, the current study demonstrated that ETR may exert an anti-inflammatory effect by suppressing the expression of inflammatory mediators and cytokines, via the downregulation of NF- $\mathrm{kB}$, Akt and the MAPK signaling pathways in LPS-stimulated macrophages. To the best of our knowledge, this is the first report of the anti-inflammatory activity of ETR in LPS-induced RAW264.7 cells. These results indicate that ETR may be a promising candidate for development as an anti-inflammatory drug.

\section{Acknowledgements}

The present study was supported by a grant from the National Institute of Biological Resources under the Ministry of Environment of the Republic of Korea (grant no. 2014-04-202). 


\section{References}

1. Kanchanapoom T, Kasai R, Chumsri P, Kraisintu K and Yamasaki K: Lotthanongine, an unprecedented flavonoidal indole alkaloid from the roots of Thai medicinal plant, Trigonostemon reidioides. Tetrahedron Lett 43: 2941-2943, 2002.

2. Soonthornchareonnon N, Sakayarojkul M, Isaka M, Mahakittikun V, Chuakul W and Wongsinkongman P: Acaricida daphnane diterpenoids from Trigonostemon reidioides (KURZ) CRAIB roots. Chem Pharm Bull (Tokyo) 53: 241-243, 2005.

3. Laroux FS: Mechanisms of inflammation: The good, the bad and the ugly. Front Biosci 9: 3156-3162, 2004

4. Bognar E, Sarszegi Z, Szabo A, Debreceni B, Kalman N, TucsekZ, Sumegi B and Gallyas F Jr: Antioxidant and anti-inflammatory effects in RAW264.7 macrophages of malvidin, a major red wine polyphenol. PLoS One 8: e65355, 2013.

5. Rhule A, Navarro S, Smith JR and Shepherd DM: Panax notoginseng attenuates LPS-induced pro-inflammatory mediators in RAW264.7 cells. J Ethnopharmacol 106: 121-128, 2006.

6. Oh YC, Jeong YH, Cho WK, Ha JH, Gu MJ and Ma JY: Anti-inflammatory and analgesic effects of pyeongwisan on LPS-stimulated murine macrophages and mouse models of acetic acid-induced writhing response and xylene-induced ear edema. Int J Mol Sci 16: 1232-1251, 2015.

7. Chen Z, Hagler J, Palombella VJ, Melandri F, Scherer D, Ballard D and Maniatis T: Signal-induced site-specific phosphorylation targets I kappa B alpha to the ubiquitin-proteasome pathway. Genes Dev 9: 1586-1597, 1995.

8. Chen Q, Chen T, Li W, Zhang W, Zhu J, Li Y, Huang Y, Shen Y and Yu C: Mycoepoxydiene inhibits lipopolysaccharide-induced inflammatory responses through the suppression of TRAF6 polyubiquitination [corrected]. PLoS One 7: e44890, 2012.

9. Ahn EK, Lee JA, Seo DW, Hong SS and Oh JS: 1 $\beta$-Hydroxy-2-oxopomolic acid isolated from Agrimonia pilosa extract inhibits adipogenesis in 3T3-L1 cells. Biol Pharm Bull 35: 643-649, 2012.

10. Ahn EK and Oh JS: Lupenone isolated from Adenophora triphylla var. japonica extract inhibits adipogenic differentiation through the downregulation of PPAR $\gamma$ in 3T3-L1 cells. Phytother Res 27: 761-766, 2013.

11. Szabó C, Thiemermann C, Wu CC, Perretti M and Vane JR: Attenuation of the induction of nitric oxide synthase by endogenous glucocorticoids accounts for endotoxin tolerance in vivo. Proc Natl Acad Sci USA 91: 271-275, 1994.

12. Guzik TJ, Korbut R and Adamek-Guzik T: Nitric oxide and superoxide in inflammation and immune regulation. J Physiol Pharmacol 54: 469-487, 2003.

13. Lee TH, Jung M, Bang MH, Chung DK and Kim J: Inhibitory effects of a spinasterol glycoside on lipopolysaccharide-induced production of nitric oxide and proinflammatory cytokines via down-regulating MAP kinase pathways and NF- $\kappa B$ activation in RAW264.7 macrophage cells. Int Immunopharmacol 13: 264-270, 2012.

14. Soromou LW, Zhang Z, Li R, Chen N, Guo W, Huo M, Guan S, Lu J and Deng X: Regulation of inflammatory cytokines in lipopolysaccharide-stimulated RAW 264.7 murine macrophage by 7-O-methyl-naringenin. Molecules 17: 3574-3585, 2012.

15. Guo LY, Hung TM, Bae KH, Shin EM, Zhou HY, Hong YN, Kang SS, Kim HP and Kim YS: Anti-inflammatory effects of schisandrin isolated from the fruit of Schisandra chinensis Baill. Eur J Pharmacol 591: 293-299, 2008.
16. Kim KS, Lee DS, Bae GS, Park SJ, Kang DG, Lee HS, Oh H and Kim YC: The inhibition of JNK MAPK and NF- $\kappa$ B signaling by tenuifoliside A isolated from Polygala tenuifolia in lipopolysaccharide-induced macrophages is associated with its anti-inflammatory effect. Eur J Pharmacol 721: 267-276, 2013.

17. Zhang G and Ghosh S: Molecular mechanisms of NF-kappaB activation induced by bacterial lipopolysaccharide through Toll-like receptors. J Endotoxin Res 6: 453-457, 2000.

18. Karin M and Ben-Neriah Y: Phosphorylation meets ubiquitination: The control of NF-[kappa]B activity. Annu Rev Immunol 18 621-663, 2000.

19. Lu YC, Yeh WC and Ohashi PS: LPS/TLR4 signal transduction pathway. Cytokine 42: 145-151, 2008.

20. Veres B, Radnai B, Gallyas F Jr, Varbiro G, Berente Z, Osz E and Sumegi B: Regulation of kinase cascades and transcription factors by a poly(ADP-ribose) polymerase-1 inhibitor, 4-hydroxyquinazoline, in lipopolysaccharide-induced inflammation in mice. J Pharmacol Exp Ther 310: 247-255, 2004.

21. Kyriakis JM and Avruch J: Mammalian MAPK signal transduction pathways activated by stress and inflammation: A 10-year update. Physiol Rev 92: 689-737, 2012.

22. Jung CH, Jung H, Shin YC, Park JH, Jun CY, Kim HM, Yim HS, Shin MG, Bae HS, Kim SH and Ko SG: Eleutherococcus senticosus extract attenuates LPS-induced iNOS expression through the inhibition of Akt and JNK pathways in murine macrophage. J Ethnopharmacol 113: 183-187, 2007.

23. Cho BO, Ryu HW, So Y, Lee CW, Jin CH, Yook HS, Jeong YW, Park JC and Jeong IY: Anti-inflammatory effect of mangostenone F in lipopolysaccharide-stimulated RAW264.7 macrophages by suppressing NF- $\mathrm{KB}$ and MAPK activation. Biomol Ther (Seoul) 22: 288-294, 2014

24. Yoo MS, Shin JS, Choi HE, Cho YW, Bang MH, Baek NI and Lee KT: Fucosterol isolated from Undaria pinnatifida inhibits lipopolysaccharide-induced production of nitric oxide and pro-inflammatory cytokines via the inactivation of nuclear factor- $\kappa \mathrm{B}$ and p38 mitogen-activated protein kinase in RAW264.7 macrophages. Food Chem 135: 967-975, 2012.

25. Kim JH, Kim YS, Hwang JW, Han YK, Lee JS, Kim SK, Jeon YJ, Moon SH, Jeon BT, Bahk YY and Park PJ: Sulfated chitosan oligosaccharides suppress LPS-induced NO production via JNK and NF- $\kappa B$ inactivation. Molecules 19: 18232-18247, 2014.

26. Choi WS, Seo YB, Shin PG, Kim WY, Lee SY, Choi YJ and Kim GD: Veratric acid inhibits iNOS expression through the regulation of PI3K activation and histone acetylation in LPS-stimulated RAW264.7 cells. Int J Mol Med 35: 202-210, 2015.

27. Huang BP, Lin CH, Chen YC and Kao SH: Anti-inflammatory effects of Perilla frutescens leaf extract on lipopolysaccharide-stimulated RAW264.7 cells. Mol Med Rep 10: 1077-1083, 2014.

28. Lin CY, Lee CH, Chang YW, Wang HM, Chen CY and Chen YH: Pheophytin a inhibits inflammation via suppression of LPS-induced nitric oxide synthase-2, prostaglandin E2, and interleukin-1 $\beta$ of macrophages. Int J Mol Sci 15: 22819-22834, 2014.

29. Park HJ, Lee HJ, Choi MS, Son DJ, Song HS, Song MJ, Lee JM, Han SB, Kim Y and Hong JT: JNK pathway is involved in the inhibition of inflammatory target gene expression and NF-kappaB activation by melittin. J Inflamm (Lond) 5: 7, 2008.

30. Xu CQ, Liu BJ, Wu JF, Xu YC, Duan XH, Cao YX and Dong JC: Icariin attenuates LPS-induced acute inflammatory responses: Involvement of PI3K/Akt and NF-kappaB signaling pathway. Eur J Pharmacol 642: 146-153, 2010. 